\title{
Psychoeducational programs in psychiatry - possibilities and limitations of their application
}

\begin{abstract}
Piotr Majewicz, Psychoeducational programs in psychiatry - possibilities and limitations of their application. Interdisciplinary Contexts of Special Pedagogy, no. 31, Poznań 2020. Pp. 149-172. Adam Mickiewicz University Press. ISSN 2300-391X. e-ISSN 2658-283X. DOI: https://doi.org/10.14746/ikps.2020.31.07

Psychoeducation is currently used in many areas of life, including psychiatry. It is difficult to imagine the modern process of treating people with mental disorders without the use of psychoeducation as a necessary, permanent element of this process, in addition to pharmacotherapy and psychotherapy. Psychoeducational programs are used primarily in the treatment of people with schizophrenia spectrum disorders and those suffering from bipolar affective disorder (BPAD). These programs are not only directed to the patient, but they are also addressed to their family members and friends. The article presents the possibilities of using selected psychoeducational programs, including the PEGASUS program, the Barcelona Psychoeducation Program and the Krakow Program for People with BPAD, as well as limitations of their application. The goals of these programs, their structure and effectiveness were also presented.
\end{abstract}

KEY WORDS: psychoeducation, psychiatry, therapeutic pedagogy, psychoeducational programs, interdisciplinarity 


\section{Introduction}

Psychoeducation, as a form of broadly understood psychosocial development support, is applicable in its various areas. It is used, among others, to acquire the skills of conducting negotiations and mediation, shape assertive skills, communication, decision-making or professional skills, including educational, managerial, interpersonal skills, etc. In general, as suggested in the name, it can be described as a process of learning specific psychological skills ${ }^{1}$, as well as acquiring or expanding knowledge in a given field.

It can be defined as "... a set of planned, structured activities aimed at the development of personal resources in the emotional, motivational, cognitive, noetic and instrumental spheres, as well as the skills to mobilise and use them in the process of coping with difficult situations, and above all increasing the sense of well-being, as a result of which a higher level of quality of life is achieved" ${ }^{2}$ It is used not only in the field of development stimulation, in health promotion and preventive measures, but also in the area of rehabilitation of people with disabilities and mental disorders.

Nowadays, psychoeducation, together with pharmacotherapy and psychotherapy, is the third pillar of the treatment process for people with mental disorders. Psychoeducation conducted as part of the therapy of the aforementioned group of people is based on an axiom assuming a close relationship between the patient's knowledge about their disease and improvement in its course. It should be noted that this statement is taken for granted in the treatment of many other diseases, including, in particular, diabetes, some cardiovascular diseases and asthma. Therefore, the inclusion of psychoeducation in treatment algorithms is now a neces-

${ }^{1}$ K. Sawicka, Socjoterapia, Methodological Centre of Psychological-Pedagogical Counselling Ministry of National Education, Warszawa 1998, p. 12.

2 P. Majewicz, Psychoedukacja jako forma stymulacji rozwoju osób z niepełnosprawnością, [in:] Psychoedukacja w procesie wspomagania rehabilitacji osób z niepełnosprawnością, ed. P. Majewicz, M. Kościółek, E. Dyduch, Wydawnictwo Naukowe Uniwersytetu Pedagogicznego, Kraków 2017, p. 22. 
sity 3 . Psychoeducation has found its special place in the treatment of mentally ill people suffering from bipolar affective disorder (BPAD) and schizophrenia spectrum disorders. The risk of developing the first of the aforementioned diseases, or BPAD, in the general population is estimated at $0.6-1.6 \%$, and after considering the entire "spectrum of the disease", it is estimated at 3-6.5\%. ${ }^{4}$ On the other hand, the risk of developing schizophrenia in the general population is approximately $1 \% 5$, with epidemiology being much greater, for example, among people with intellectual disabilities, in the case of whom from $2 \%$ to $6 \%$ develops psychoses during their lifetime. ${ }^{6}$ Among all chronic diseases that gradually transform into disability, psychoses are the most complex, starting from the criteria for their diagnosis, classification, through the explanation of pathomechanisms, establishing a management procedure, and ending up with the development of effective treatment methods. ${ }^{7}$

In most cases, schizophrenia is characterised by a chronic course, and only about $10 \%$ of patients recover fully after one episode. ${ }^{8}$ In such a situation, the necessity to undertake rehabilitation measures is indisputable. Any form of help leading to the improvement of the functioning of the affected person is important, and even necessary. According to William Anthony ${ }^{9}$ the process of rehabilitation of the mentally ill is "Purposeful activity that is to pro-

${ }^{3}$ F. Colom, E. Vieta, Podręcznik psychoedukacji w zaburzeniach afektywnych dwubiegunowych, MediPage, Warszawa 2009, p. 35.

${ }^{4}$ A. Bilikiewicz, J. Landowski, P. Radziwiłłowicz, Psychiatria. Repetytorium, Wydawnictwo Lekarskie PZWL, Warszawa 1999, pp. 94-95.

${ }^{5}$ L. Cierpiałkowska, Psychopatologia, Wydawnictwo Naukowe SCHOLAR, Warszawa 2009, p. 272.

${ }^{6} \mathrm{~K}$. Bobińska, P. Gałecki, Zaburzenia psychiczne u osób upośledzonych umysłowo, Wydawnictwo Continuo, Wrocław 2010, p. 25.

7 S. Kowalik, Stosowana psychologia rehabilitacji, Wydawnictwo Naukowe SCHOLAR, Warszawa 2018, p. 139.

${ }^{8}$ A. Bilikiewicz, J. Landowski, P. Radziwiłłowicz, Psychiatria. Repetytorium, Wydawnictwo Lekarskie PZWL, Warszawa 1999, p. 62.

${ }^{9} \mathrm{~S}$. Kowalik, Stosowana psychologia rehabilitacji, Wydawnictwo Naukowe SCHOLAR, Warszawa 2018, pp. 144-145. 
vide mentally ill people with the possibility to use all physical, emotional, intellectual and social resources to function in a natural environment, to improve themselves through a continuous learning process and to take up permanent work with the least possible support from professional services". The main goal is therefore the activation of mentally ill people, their inclusion in the normal course of social life and creating prospects for further development. Thus, multidisciplinary, interdisciplinary therapeutic and supporting activities for the functioning of both patients and their families are a challenge not only for modern psychiatry and psychology, but also for special education.

In addition to pharmacotherapy and psychotherapy, psychoeducation is one of the forms of active action that enable the achievement of the aforementioned goals. In medicine, it is defined as "an intervention with systematic, structured, and didactic knowledge transfer for an illness and its treatment, integrating emotional and motivational aspects to enable patients to cope with the illness and to improve its treatment adherence and efficacy". ${ }^{10}$ The goals and tasks of psychoeducation in psychiatry, according to Francesc Colom ${ }^{11}$, one of the most eminent specialists in this field, are primarily to strengthen the patient by promoting awareness and proactive attitude, teaching ways of coping and living with a chronic disease, including early diagnosis of relapse symptoms, coping during a crisis, improving communication, shaping lifestyle. In addition, a change in behaviour and attitudes related to the disease is important. All this is supposed to replace guilt with responsibility, helplessness with a proactive attitude, and denying the disease with its awareness. In order to achieve the aforementioned goals, not only competence in the field of psychiatry and psychology, but also education, and more specifically didactics, is needed. Psychological and medical knowledge

${ }^{10}$ H. Ekhtiari, T. Rezapour, R.L. Aupperle, M.P. Paulus, Neuroscience-informed psychoeducation for addiction medicine: A neurocognitive perspective, "Progress In Brain Research" 2017, Vol. 235, pp. 239-264.

$11 \mathrm{~F}$. Colom, Keeping therapies simple: psychoeducation in the prevention of relapse in affective disorders, “The British Journal of Psychiatry" 2011, 198(5), pp. 338-340. 
and skills are essential here, but as Francesc Colom and Eduardo Vieta emphasise12, "not always a wise doctor has great didactic skills". Hence the necessity to supplement the aforementioned competence with educational skills. It can be said that psychoeducation in psychiatry is a kind of platform for the integration of medical, psychological and educational actions. Knowledge and educational skills in psychoeducation are an indispensable element conditioning its effectiveness. Psychoeducation is primarily a form of education, so it requires knowledge of both teaching and learning strategies and methods, as well as the possibility of using teaching aids in the work with a specific group of people, in this case adults. ${ }^{13}$

The problems of education and rehabilitation of chronically ill people, including those with mental disorders, are of interest to therapeutic pedagogy. So far, however, not many studies have concerned the specific nature of working with this group of people. Despite the needs of the practice, to some extent it was a neglected area. For a long time, therapeutic pedagogy has focused primarily on the problems of people with chronic somatic diseases and motor organ dysfunction, while the issues related to the rehabilitation of people with mental disorders have constituted a marginal area of exploration. In the history of Polish therapeutic pedagogy, only a few publications related to this subject can be found. ${ }^{14}$ Currently, the awareness of the needs in the discussed area is much greater, which was particularly emphasised by Andrzej Witusik, Stanisław

${ }^{12}$ F. Colom, E. Vieta, Podręcznik psychoedukacji w zaburzeniach afektywnych dwubiegunowych, MediPage, Warszawa 2009, p. 28.

${ }^{13}$ P. Majewicz, J. Wolny, Psychoedukacja jako płaszczyzna integracji działań psychologicznych, psychiatrycznych oraz pedagogicznych, "Humanum - Międzynarodowe Studia Społeczno-Humanistyczne" 2017, no. 26(3), pp. 29-48.

${ }_{14}$ E.g. M. Boratyńska-Dąbrowska, Postępowanie pedagogiczne wobec dzieci z rozpoznaniem schizofrenii, [in:] ed. R. Janeczko, Kształcenie dzieci w zakładach leczniczych, WSiP, Warszawa 1991, pp. 415-422; P. Majewicz, A. Zawadzki, Wspomaganie rozwoju dzieci $z$ zaburzeniami emocjonalnymi w młodszym i średnim wieku szkolnym, [in:] W. Pilecka, Majewicz, A. Zawadzki, Jak wspomagać psychospołeczny rozwój dzieci niepełnosprawnych somatycznie. Wydawnictwo Edukacyjne, Kraków 1999, pp. 77-118. 
Leszta, Dorota Podgórska-Jachnik and Tadeusz Pietras in the book entitled "Schizofrenia w kontekście nauk społecznych. Osoba chora na schizofrenię w obszarze zainteresowań pedagogiki specjalnej" ["Schizophrenia in the context of social sciences. A person suffering from schizophrenia in the area of interest of special education" $].{ }^{15}$ The authors emphasised the need to include a special education teacher on the basis of equal rights in the diagnostic and therapeutic ativities carried out in the process of social inclusion of people with schizophrenia. It is worth noting that such initiatives are also undertaken in other countries, for example in Germany, where the PEGASUS psychoeducational program intended for people with schizophrenia spectrum disorders has been developed at the level of full interdisciplinarity.

\section{Psychoeducational programs intended for people with schizophrenia}

One of the best-developed psychoeducational programs, both in terms of content and didactic values, addressed to people with schizophrenia spectrum disorders is PEGASUS (Psychoedukative Gruppenarbeit mit schizophren und schizoaffektiv erkrankten Menschen). ${ }^{16}$ Work on the aforementioned program began in 1989 in Bilefeld, East Westphalia, Germany. The theoretical basis of the program included the results of pioneering research by Luciano Ciompi, a Swiss psychiatrist. The program is based on the concept of coping with vulnerability to stress in the context of a dynamic biopsychosocial model located in systems theory. Such an approach allows for the integration of a large number of both older and wellverified results of exploration, as well as new results of research on schizophrenia within the framework of the aforementioned model.

${ }^{15}$ A. Witusik, S. Leszto, D. Pogdgórska-Jachnik, T. Pietras, Schizofrenia w kontekście nauk spotecznych. Osoba chora na schizofrenię w obszarze zainteresowań pedagogiki specjalnej. Wydawnictwo Continuo, Wrocław 2015.

${ }^{16} \mathrm{G}$. Wienberg, Ch. Walther, M. Berg, Psychoedukacja grupowa $z$ schizofrenii i zaburzeniach schizoafektywnych. Program PEGASUS, Wydawnictwo DK Media Poland, Warszawa 2015. 
From the very beginning of the program, psychiatrists, psychologists and educators were involved in its development. In this case, it can be stated that the full integration of activities in the field of medical and social sciences took place, which is implied by the adopted biopsychosocial model. The first program developed in an interdisciplinary convention was verified in practice in 1992-1994 in centres belonging to the Bodelschwinghsche Stiftungen Bethel (diaconal organization for people with disabilities and mental disorders) and in municipal facilities in Bilefeld. As a result, in 1995, the first textbook concerning group psychoeducation for people suffering from schizophrenia and schizoaffective disorders was published. This study, as a result of research and experience of the educators, was modified in the following years. Currently, the sixth edition of the textbook, which was published in 2013 in Germany, and in 2015 also in Poland, is in use. It is the most accurate and comprehensive version of the textbook, with a number of updates and supplements. The textbook is accompanied by a CD containing the materials necessary for the classes, assigned to individual sessions. They can be printed for each participant or displayed using a projector. Undoubtedly, teaching aids prepared in this way considerably simplify the sessions.

In addition, changes to the course of individual sessions were introduced for didactic reasons. Because of the fact that the PEGASUS program is intended for adults, it was necessary to include the specific nature of education in this age group to a greater extent. Adults usually try to avoid mistakes in the education process to a lesser extent, while they are more interested in checking and enriching their previous experience and knowledge. Particular attention has been paid to the extent to which the provided information and the acquired skills are important, meaningful and, above all, useful in everyday life, and to the extent to which they allow not only for a better understanding of the nature of the disease, its course and therapy process, but also for the improvement of psychosocial functioning and, consequently, the increase in quality of life. Therefore, the main goals of the program implementation were 
focused on: expanding knowledge about the disease and its treatment options, reducing anxiety and uncertainty, supporting positive self-esteem, relativising stigmatising and false ideas about the disease, strengthening active disease management and co-responsibility for treatment, improving well-being, supporting partnership and cooperation of patients and specialists according to the motto: "negotiating instead of treating". 17

The achievement of these goals is possible thanks to the integration of knowledge and skills in the field of medical and social sciences. Only the combination of expertise in the field of psychopathology, as well as didactic and psychological skills related to the group activities determines success. Therefore, it is best when the sessions are conducted by two moderators representing different professional groups. Before starting the program, it is necessary to assign roles and practice their fulfilment in individual sessions. In fact, there is only one subject area that absolutely requires the participation of a physician, either as a moderator or as an assistant. These are sessions devoted to the use of pharmacological agents (part II of the PEGASUS program). This is because, in this area, it is not enough to know the groups and types of drugs, but fluent knowledge of the dosage, possible side effects, interactions with other agents, etc. is required. In the remaining sessions, the psychiatrist may of course be one of the moderators, but it is not absolutely necessary, this function may be performed by an educator and a psychologist. It should be emphasised that the moderators should have thorough preparation, not only of a theoretical nature, but also practical one, and thus up-todate knowledge of schizophrenia and its treatment options, as well as pedagogical and psychotherapeutic competence, supported by many years of experience in working with people suffering from schizophrenia spectrum disorders. People prepared in this way can fully use the potential of the PEGASUS program.

17 G. Wienberg, Ch. Walther, M. Berg, Psychoedukacja grupowa z schizofrenii i zaburzeniach schizoafektywnych. Program PEGASUS, Wydawnictwo DK Media Poland, Warszawa 2015, p. 10. 
The entire program consists of three parts, the first of which covers information about the disease, the second part deals with treatment options, while the third one focuses on self-help options in case of the presence of the disease or increased susceptibility to the disease. As part of the aforementioned parts of the program, a total of 14 sessions lasting approximately 60 minutes are conducted:

"Session 1. Get-together activities in the group, goals and content, rules of group work, previous knowledge of the participants.

\section{PART I. DEVELOPING A MODEL OF DISORDERS}

Session 2. The concept of schizophrenia, symptoms of the disease, the concept of susceptibility, three-phase model of schizophrenia.

Session 3. Possible factors of susceptibility to schizophrenia.

Session 4. Development of acute schizophrenic psychoses.

Session 5. Experience of acute psychosis.

Session 6. Stress, resistance, overload.

Session 7. The course and recovery from schizophrenic psychosis

\section{PART II. MOST IMPORTANT TREATMENT METHODS}

Session 8. Antipsychotics and their effects.

Session 9. Adverse side reactions and how to deal with them. Risk of post-treatment complications.

Session 10. Co-responsibility of patients, cooperation with a physician.

Session 11. Psychotherapeutic sessions and treatment options.

PART III. PREVENTION OF RELAPSE AND ANTI-CRISIS MANAGEMENT

Session 12. Individual prodromal symptoms and response possibilities.

Session 13. Gradual plan for overcoming the crisis. 
Session 14. Individual anti-crisis plan and completion of the group's work". 18

The program should be treated as a supplement and not as a substitute for information provided by the attending physician. Psychoeducation is primarily a component of a long-term treatment or support process, the participants of which should include not only people suffering from schizophrenia spectrum disorders, but also members of their families. This concerns bifocal action, so apart from psycho-educational groups for patients, activities with similar content for their family members should be organised.

An interesting suggestion in this regard is the program entitled "Rodzina w opresji - psychoedukacja rodzin osób niepetnosprawnych chorujacych psychicznie" ["Family in oppression - psychoeducation of families of mentally ill people"]19 by Wojciech Kordas, Katarzyna Warchol, Agnieszka Kurtyka, Krzysztof Walczewski, Józef Bogacz and Piotr Słowik. The program was completed under the supervision of the T. Dec Mentally Ill Assistance Foundation in Cracow, and financed by the State Fund of Rehabilitation of Handicapped People, the Lesser Poland Branch as part of module B of the program entitled "Partner III - support for projects implemented for the benefit of disabled people by non-governmental organizations". Psychoeducation sessions according to the aforementioned program were conducted at Józef Babiński Specialist Hospital in Cracow.

The main aim of the program is to "restore normality in the family", and more precisely to lower the level of stress, support the communication process, restore the proper structure of the family, and stop the process of family isolation/social drift. The program consists of three parts in which 14 scenarios of activities lasting ap-

${ }^{18}$ G. Wienberg, Ch. Walther, M. Berg, Psychoedukacja grupowa z schizofrenii $i$ zaburzeniach schizoafektywnych. Program PEGASUS, Wydawnictwo DK Media Poland, Warszawa 2015, pp. 5-6.

19 W. Kordas, K. Warchoł, A. Kurtyka, K. Walczewski, J. Bogacz, P. Słowik, Psychoedukacja i psychoprofilaktyka dla rodzin osób chorujących na schizofrenię - raport z realizacji projektu, “Hygeia Public Health” 2014, 49(1), pp. 120-126. 
proximately 90 minutes are carried out. The first part is intended to collect individual stories of family members, information on the circumstances of the disease in the family, as well as the needs and expectations related to participation in group sessions. The second part of the program is aimed at constructing knowledge about the disease from a clinical perspective through lectures, case studies, and free discussion. In turn, the third part, focuses on creating crisis plans and problems of social exclusion. These issues are discussed in seven subsequent points, which also constitute a kind of guidelines for taking action in a crisis situation: (1) people to contact in a crisis situation; (2) symptoms that indicate relapse; (3) the behaviour of the patient, which is a sign of well-being; (4) elements which help and do not help the patient or are a source of additional stress (5); (6) elements which are helpful and not helpful (7).

The authors also indicate necessary supplements to the program, namely a subject area devoted to social and legal issues. Families of the affected people very often do not know where and how to seek help, including financial help and security for the future. In addition, information is needed on the situations in which various legal and medical procedures can be used, for example undertaking treatment without the patient's consent or the problem of incapacitation.

\section{Psychoeducational programs for people suffering from bipolar affective disorder (BPAD)}

The Barcelona Psychoeducation Program is the most famous program with proven effectiveness for people with bipolar disorder. ${ }^{20}$

The program was based primarily on a medical model and to a much lesser extent on a biopsychosocial basis. Hence, the main goal is to contribute together with pharmacotherapy and psycho-

${ }^{20}$ F. Colom, E. Vieta, Podręcznik psychoedukacji w zaburzeniach afektywnych dwubiegunowych, MediPage, Warszawa 2009. 
therapy to cure the patient or at least alleviate symptoms. The empirical indicator of psychoeducation understood in this way is, first of all, the reduction in the number of disease episodes and the number of hospitalisations, because the complete "cure" of the disorder is, in a sense, a utopia in as many as $90 \%$ cases of mental disorders. Other indicators, such as the improvement of the quality of life, the subjective sense of increased well-being, are among the lower-order indicators that can be considered, from the perspective of the medical model, as "soft" and, at the same time, much less important indicators, because of the fact that they do not reflect the achievement of basic goals, that is, an objective improvement of health, the "hard" indicator of which is the reduction in the number of episodes, and thus also in the cases of hospitalisation. Nevertheless, the improvement of social functioning, the subjective sense of increased well-being and quality of life are important elements of the so-called "perfect scenario", in which, after achieving the primary goals related to treatment, including gaining knowledge about the disorder, the ability to early diagnose new episodes, the increase in treatment adherence or stress control and counteracting suicidal behaviour, the importance of the above-mentioned subjective aspects of psychosocial functioning is also emphasised.

Thus, the mechanisms of psychoeducation in connection with its goals create a hierarchical system in which tasks related to the elementary goals of psychoeducation based on the medical model are of crucial importance, and a secondary, complementary role is played by tasks aimed at improving well-being and quality of life.

The presented assumptions were expressed both in the structure and in the principles of practice of the Barcelona Psychoeducation Program. The program consists of five parts, the first of which is information about the disease, the second one concerns treatment adherence, the third one is about psychoactive substance abuse, while the next part includes information and procedures in the event of a new episode of illness, and the last one is about the importance of regularity of habits in everyday life and coping with stress. 
As part of the aforementioned subjects, 21 session scenarios are carried out at weekly intervals.

"Session 1. Introduction. Presentation of the group and its rules

Chapter 1. Knowledge about the disorder

Session 2. What is bipolar affective disorder?

Session 3. Aetiological factors and causes of the episode

Session 4. Symptoms 1: mania and hypomania

Session 5. Symptoms 2: depression and hypomania

Session 6. Development of the disorder and prognosis

Chapter 2. Treatment adherence

Session 7. Treatment 1: mood stabilisers

Session 8. Treatment 2: Medication for the treatment of mania

Session 9. Treatment 3: Antidepressants

Session 10 Concentration of mood stabilisers in the serum

Session 11. Pregnancy and genetic counselling

Session 12. Psychopharmacology and alternative therapies

Session 13. Risk associated with discontinuation of treatment

Chapter 3. Avoiding psychoactive substance abuse

Session 14. Psychoactive substances: risk in bipolar disorder

Chapter 4. Early diagnosis of new episodes

Session 15. Early diagnosis of mania and hypomania episodes

Session 16. Early diagnosis of depressive and mixed episodes

Session 17. What to do when a new episode is diagnosed?

Chapter 5. Regularity of habits and coping with stress

Session 18. Regularity of habits

Session 19. Stress control techniques

Session 20. Problem solving strategies

Session 21. End" 21

${ }^{21}$ F. Colom, E. Vieta, Podręcznik psychoedukacji w zaburzeniach afektywnych dwubiegunowych, MediPage, Warszawa 2009, p. 36. 
According to the authors of the program, group sessions for 8-12 people should be conducted by several therapists, preferably one main instructor and two co-therapists, and they should be people who have completed training in this field. The authors recommend psychoeducation to be conducted by a psychologist or psychiatrist experienced in working with a group, as well as in the treatment of bipolar disorders.

Each meeting lasts approximately 90 minutes. The initial 15-20 minutes is dedicated to the so-called "warm-up" and includes informal conversations on any topics, then a free discussion about the psycho-educational work is conducted, and questions about any unclear content of the previous session are asked. The next 40 minutes is the main part of the session, which is carried out in the form of an interactive lecture concerning the current topic. During the session, patients can ask questions, and in some situations group exercises are conducted, graphs are drawn, or a discussion is held to ensure that the discussed content is properly understood by participants.

The session ends with an approximately 30-minute discussion on the subject of the meeting, moreover, educational materials containing the most important content related to a given topic of the session are distributed. These materials are written in a clear way, so that they are understandable to people who have no preparation in the field of psychiatry and psychology. It is worth noting that they are often used by patients to conduct some kind of psychoeducation of their families, although the authors of the program for patients' family members propose a separate program.

In addition to educational materials, for some time a form of "homework" was proposed to recall and consolidate knowledge, but in reality these tasks were rarely performed by the participants and over time the authors of the program abandoned their use, despite the fact that they found them beneficial.

In addition to the full version of the program, its shorter form, intended for people over 55 years of age is also used, because some problems present in the content of the standard program do not usually apply to this age group, e.g. the topic of bipolar disorders 
and pregnancy. There is also a shortened version of the program, recommended in situations where there are logistical constraints, lack of full professional preparation of the therapists or problems with patient compliance with a long-term schedule. The shortened version of the program includes eight sessions:

"Session 1. Concept and causes

Session 2. Symptoms I: mania and hypomania

Session 3. Symptoms 2: depression and mixed states

Session 4: Development and prognosis

Session 5: Mood stabilisers

Session 6: Medication applied in manic episodes and antidepressants

Session 7: Learning to diagnose episodes

Session 8: What to do when decompensation occurs?"22

However, it should be noted, that there are no empirical data proving that the shortened program is as effective as its standard 21-session version.

The eight-session structure is also characteristic of the Krakow Psychoeducation Program for people with BPAD, entitled "Getting used to bipolar affective disorder" 23 , which includes the following topics:

"Organizational and introductory meeting

Session 1. Basics of knowledge about bipolar affective disorder

Session 2. Treatment of bipolar affective disorder

Session 3. Therapeutic cooperation Treatment adherence

Session 4. Individual picture of BPAD

Session 5. Early relapse diagnosis and early response system.

22 F. Colom, E. Vieta, Podręcznik psychoedukacji w zaburzeniach afektywnych dwubiegunowych, MediPage, Warszawa 2009, p. 37.

${ }^{23}$ G. Mączka, B. Grabski, J.K. Gierowski, D. Dudek, Psychoedukacja grupowa w kompleksowym leczeniu choroby afektywnej dwubiegunowej - doświadczenia krakowskie, "Psychiatria Polska" 2010, volume XLIV, no. 1, pp. 89-100. 
Session 6. Lifestyle conducive to maintaining health.

Session 7. Coping with stress and problem solving.

Session 8. Summary. Questions. Feedback".

The program has been developed in the convention of a cognitive paradigm, in which the idea of concordance therapy, and thus therapy assuming that a human being, as a rational consumer, makes decisions that make sense to them, functions. Therefore, the implementation of the program requires full conscious cooperation of patients with the therapists, who are a psychologist and psychiatrist trained in cognitive behavioural therapy. The entire program consists of eight sessions conducted in the form of lectures and workshops, each of which lasts approximately 90 minutes. It should be noted that the lecture part is supplemented with the participants' own experience, which allows for the emphasis of the individual picture of the disease, and also ensures interactivity of the relationship. Each participant is provided with printed educational materials containing information related to the topic covered on a given day. The group should consist of 10 to 15 people.

Before the implementation of the main program begins, a meeting is organised to introduce participants to the subject, content and form of sessions, as well as to present the rules of participation in the group. Besides, it aims at motivating to active participation in the program. The two initial sessions are designed to provide basic information about BPAD, including symptoms, the course of the disease, and possible treatments. Based on this elementary knowledge of BPAD, another five sessions are conducted to reduce the impact of the disease on patients' functioning, so they can be considered essential for the entire program. In this regard, attention is paid to those aspects of the disease that the patient can and should have a direct impact on, including through the development of therapeutic cooperation, the ability to diagnose symptoms indicative of an impending new episode, promotion of a healthy lifestyle, as well as the ability to cope with stress in difficult situations. The program ends with a session summarising all the conducted psychoeducational activities. 


\section{Effectiveness of psychoeducational programs}

Psychoeducation in psychiatry has a fairly well-established position, supported by numerous studies on the effectiveness of the conducted programs. As shown by the results of reliable, randomised studies on the effectiveness of the Barcelona Psychoeducation Program, within 2 years of its completion, a significant reduction in the number of BPAD relapses and the duration of hospitalization in patients participating in psychoeducation for a period of 21 weeks is visible. ${ }^{24}$ Moreover, the results of randomised trials covering a long period of time, of as long as 5 years ${ }^{25}$ also confirm the high effectiveness of psychoeducational activities. The effectiveness of this form of support in the treatment of people with bipolar disorder has also been demonstrated in the results of the analysis of 13 other scientific reports based on randomised trials. ${ }^{26}$ The aforementioned research reports were selected from among 161 documents concerning psychoeducation of people with BPAD, included in the PubMed and SCOPUS databases. Only 13 articles meeting the highest methodological requirements were selected for the final analysis. Such a rigorous approach allows for a reliable inference about the effectiveness of psychoeducation in the treatment of people with bipolar BPAD. It should be noted that eight out of 13 analysed studies concerned psychoeducation conducted only with patients, four concerned only family members and guardians, and one study con-

${ }^{24}$ F. Colom, E. Vieta, A. Martinez-Aran, M. Reinares, J.M. Goikolea, A. Benabarre, C. Torrent, M. Comes, B. Corbella, G. Parramon, J. Corominas, A randomized trial on the efficacy of group psychoeducation in the prophylaxis of recurrences in bipolar patients whose disease is in remission, "Arch Gen Psychiatry" 2003, 60(4), pp. 402-407.

25 F. Colom, E. Vieta, J. Sánchez-Moreno, R. Palomino-Otiniano, M. Reinares, J.M. Goikolea, A. Benabarre, A. Martínez-Arán, Group psychoeducation for stabilised bipolar disorders: 5-year outcome of a randomised clinical trial, "The British Journal of Psychiatry" 2009, 194(3), pp. 260-265.

26 T.A. Batista, Ch. von Werne Baes, M.F. Juruena, Efficacy of psychoeducation in bipolar patients: systematic review of randomized trials, "Psychology and Neuroscience" 2011, 4(3), pp. 409-416. 
cerned psychoeducation in a combined group - patients and their families and friends.

Most of the analysed research reports indicate that psychoeducation significantly improves treatment adherence in patients, including taking medications. Moreover, it usually limits the number of consecutive episodes and the duration of hospitalisation, but it should be noted that in two studies no significant benefits in both the clinical course of the disease and the number of days of hospitalisation of patients covered by the program were found. In four analysed research reports, the impact of the program on the psychosocial functioning of psychoeducation participants was considered. Improvement in general social and professional functioning was indicated, in addition to that, attention was also paid to the benefits of psychoeducation organised for family members and guardians, namely increase in knowledge about the disease, reduction in stress, development of social skills, and besides modification of beliefs about the relationship between problems present in life and the patient's disease were emphasised.

Research concerning the Krakow program ${ }^{27}$ shows that people suffering from BPAD, especially those suffering from chronic health condition, noticed a clear change in the philosophy of approach to treatment, expressed in the doctor-patient relationship, availability of information, and noticing the psychological aspects of the disorder. The participants recognised the universality of experience and the possibility to meet people with similar experience, as well as awakening hope, and the possibility of mutual support as a valuable opportunity, and emphasised the de-stigmatising value of meetings, a kind of release from guilt for living with the label of "mentally ill". Therefore, it can be concluded that from the point of view of the patient, psychoeducation largely satisfies the need to get familiar with the disease and to actively cooperate in the treatment process.

27 G. Mączka, B. Grabski, J.K. Gierowski, D. Dudek, Psychoedukacja grupowa w kompleksowym leczeniu choroby afektywnej dwubiegunowej - doświadczenia krakowskie, "Psychiatria Polska" 2010, volume XLIV, no. 1, pp. 89-100. 
In turn, the assessment of the effectiveness of psychoeducation in groups of patients suffering from schizophrenia and depression ${ }^{28}$ indicates that the main achievement is a favourable change in attitudes towards taking medications, which implies better cooperation with the therapist and more conscious participation of the patient in the recovery process, and in the later period it is likely to improve health. On the other hand, psychoeducation is not related to the reduction of psychopathological symptoms occurring during hospitalisation. Moreover, the improvement in the functioning of patients in the ward observed during treatment is independent of psychoeducation.

It should also be added that the increase in knowledge about schizophrenia does not always have a positive effect on the subjective assessment of the quality of life. Moreover, as a result of educational activities, there may be an increase in criticism of the disease, which in turn may contribute to a lower quality of life. ${ }^{29}$

Nevertheless, people suffering from schizophrenia have a generally positive attitude towards activities conducted both in 24-hour and day hospital wards. Patients emphasise, above all, the possibility of broadening their knowledge about the disease and finding ways to deal with it. The main expectation of affected people is to learn how to control the effects of schizophrenia so that they can participate in life in the fullest possible way. In addition, they also pay attention to the possibility of sharing experience with other participants of the sessions, as well as receiving support and improving mood. ${ }^{30}$

The results of the research concerning the effects of psychoeducation addressed to family members of people suffering from schiz-

${ }^{28}$ R. Popławska, A. Czernikiewicz, A. Szulc, B. Galińska, B. Konarzewska, I. Rudnik-Szałaj, Ocena efektywności psychoedukacji w grupach pacjentów psychotycznych $i$ depresyjnych - badania pilotażowe, "Psychiatria Polska" 2004, Vol. 38, no. 3, pp. 433-442.

${ }^{29}$ M. Chądzyńska, B. Kasperek, K. Spiridonow, Zmienne kliniczne i demograficzne a jakość życia osób przewlekle chorych na schizofrenię, "Wiadomości Psychiatryczne" 2001, 4, pp. 275-281.

${ }^{30}$ M. Chądzyńska, J. Meder, K. Charzyńska, Uczestnictwo w psychoedukacji osób chorych na schizofrenię - analiza zajęć z perspektywy pacjentów, "Psychiatria Polska" 2009, volume XLIII, number 6, pp. 693-704. 
ophrenia $^{31}$ show that, contrary to initial expectations, the highest value resulting from the participation in sessions is the obtained support. By reinterpreting this result, it is possible to indicate its possible determinants, first of all a family with a mentally ill person functions in a specific situation, where negative emotions are present, including hostility towards the patient caused by a disorder in the functioning of the system, and a critical evaluation by the social environment is another burdening factor. Hence, the opportunity to share experience with other people in a similar situation, and the awareness of the lack of uniqueness of own situation certainly constitutes a strong component of support in the event of the disease of one of the family members. Other beneficial effects of family psychoeducation include improved understanding of the disease and the patient, as well as better understanding of oneself and own way of reacting, and lowering the subjective sense of being burdened with the disease.

\section{Conclusion - conditions and limitations of using psychoeducational programs}

At the end of the review of psychoeducational programs used in psychiatry, including the presentation of their goals, structure, method of implementation and effectiveness, it is worth mentioning the possible limitations of this form of activities and the conditions for the implementation of sessions. First of all, it is necessary to consider the economic, logistic, competence- and patient-related, i.e. the willingness to cooperate, the severity of the disease, aspect etc. From the economic point of view, the psychoeducational group is a relatively cheap form of supplementing pharmacological treatment and psychotherapy. Although the best known programs indicate the need to employ several people to carry out sessions and they recommend a long duration period, of up to six months (Barcelona Psy-

31 W. Kordas, K. Warchoł, A. Kurtyka, K. Walczewski, J. Bogacz, P. Słowik, Psychoedukacja i psychoprofilaktyka dla rodzin osób chorujacych na schizofrenie - raport $z$ realizacji projektu, "Hygeia Public Health” 2014, 49(1), pp. 120-126. 
choeducation Program), the benefits in the form of reduced number of hospitalisations and relapses are undeniable. Psychoeducation also requires a room that is devoid of external stimuli and provides sufficient space for the implementation of the program, including U-shaped seating space, role play, blackboard etc. It is also necessary to provide teaching materials, including educational films, a multimedia projector, wall boards, writing and painting tools, and the preparation of educational materials for participants.

People developing the program and therapist should represent various specialities, including psychiatry, psychology and education. The PEGASUS program is an unquestionable model in terms of such an interdisciplinary approach to psychoeducation. On the other hand, in everyday practice there is a huge variation in this area, which is indicated by research conducted by Małgorzata Chądzyńska, Joanna Meder, Katarzyna Charzyńska and Anna Drożdżyńska. ${ }^{32}$ Among people creating psychoeducational programs for patients with schizophrenia, there is $34 \%$ of psychologists, $24 \%$ of psychiatrists, $16 \%$ of occupational therapists, $14 \%$ of nurses, $8 \%$ of social workers and $4 \%$ of representatives of other professions. Similarly, sessions are most often conducted by psychologists - $63 \%$, by occupational therapists - 19\%, and occasionally by psychiatrists, nurses and addiction therapy assistants. Therefore, also in Poland, psychoeducation classes are conducted by specialists from outside psychiatry and psychology, including occupational therapists, who are often graduates of special education. Of course, everyone who creates programs and conducts sessions should have appropriate competence in this field, and above all, current knowledge of psychopathology, group work skills, therapeutic and pedagogical competence, as well as practical experience.

On the other hand, the basic expectations towards participants oscillate mainly around their motivation to participate in the sessions. It is advisable that the participants show interest and express their

32 M. Chądzyńska, J. Meder, K. Charzyńska, A. Drożdżyńska, Psychoedukacja dla osób chorujących na schizofrenię - wstępna analiza sposobów prowadzenia zajęć, "Postępy Psychiatrii i Neurologii" 2011, no. 20(3), pp. 201-206. 
readiness to actively participate in psychoeducation. There is also a number of limitations regarding active participation in sessions, related to the course of the disease and the manifested symptoms. Francesc Colom and Eduard Vieta ${ }^{33}$ emphasise that the patient should be in a balanced mood, not in the acute phase of the disease, for example, a person in the manic phase should not absolutely participate in sessions, and it is not recommended to include people with hypomania, because moria, absence of mind and the tendency to start quarrels are factors that are not conducive to building group solidarity. Patients who, despite their balanced mood, display negative or depressive thoughts, require special treatment, as the group may begin to solidarise with such beliefs. Moreover, patients with severe depression should not be included in the group (retardation, problems with memory and attention). The appearance of psychotic symptoms should be the reason for exclusion from the group. In such a situation, the patient will be able to continue the program in the next group. Apart from the difficulties resulting from the course of the disease, there are also threats to the continuation of psychoeducation due to personality disorders and the abuse of psychoactive substances. It is mainly for these reasons that approximately $25 \%$ of people give up further participation in sessions.

Moreover, in order to create optimal psychoeducation for people with mental disorders, certain conditions, mainly concerning contact with specialists and the availability of support outside the sessions, should be provided ${ }^{34}$. Therefore, an "open door policy", which is total flexibility concerning unplanned patient visits, especially when a relapse is suspected, should be adopted. It would be a misunderstanding to educate the affected person to recognise symptoms early without being able to obtain prompt intervention. Secondly, "team cooperation" is necessary, as psychoeducation only

${ }^{33}$ F. Colom, E. Vieta, Podręcznik psychoedukacji w zaburzeniach afektywnych dwubiegunowych, MediPage, Warszawa 2009, pp. 40-43.

${ }^{34} \mathrm{~F}$. Colom, Keeping therapies simple: psychoeducation in the prevention of relapse in affective disorders, "The British Journal of Psychiatry" 2011, 198(5), pp. 338-340. 
makes sense under conditions where multidisciplinary approach is available. It concerns primarily the possibility of using a specific type of support. The third necessary condition for success in psychoeducation is the development and maintenance of a "therapeutic relationship based on trust, not authority". Therefore, cooperation, openness and trust in mutual relations are promoted, and at the same time in psychoeducation the pathogenic model of dependence between the dominant therapist and passive patient is avoided.

\section{References}

Batista T.A., von Werne Baes C.H., Juruena M.F., Efficacy of psychoeducation in bipolar patients: systematic review of randomized trials, "Psychology and Neuroscience" 2011, 4(3), pp. 409-416.

Bilikiewicz A., Landowski J., Radziwiłłowicz P., Psychiatria. Repetytorium, Wydawnictwo Lekarskie PZWL, Warszawa 1999.

Bobińska K., Gałecki P., Zaburzenia psychiczne u osób upośledzonych umystowo, Wydawnictwo Continuo, Wrocław 2010.

Boratyńska-Dąbrowska M., Postępowanie pedagogiczne wobec dzieci z rozpoznaniem schizofrenii, [in:] ed. R. Janeczko, Kształcenie dzieci w zakładach leczniczych, WSiP, Warszawa 1991, pp. 415-422.

Cierpiałkowska L., Psychopatologia, Wydawnictwo Naukowe SCHOLAR, Warszawa 2009.

Chądzyńska M., Kasperek B., Spiridonow K., Zmienne kliniczne i demograficzne a jakość życia osób przewlekle chorych na schizofrenię, „Wiadomości Psychiatryczne" 2001, 4, pp. 275-281.

Chądzyńska M., Meder J., Charzyńska K., Uczestnictwo w psychoedukacji osób chorych na schizofrenię - analiza zajęć z perspektywy pacjentów, „Psychiatria Polska” 2009, volume XLIII, number 6, pp. 693-704.

Chądzyńska M., Meder J., Charzyńska K., Drożdżyńska A., Psychoedukacja dla osób chorujących na schizofrenię - wstępna analiza sposobów prowadzenia zajęć, „Postępy Psychiatrii i Neurologii" 2011, no. 20(3), pp. 201-206.

Colom F., Keeping therapies simple: psychoeducation in the prevention of relapse in affective disorders, “The British Journal of Psychiatry" 2011, 198(5), pp. 338-340.

Colom F., Vieta E., Sánchez-Moreno J., Palomino-Otiniano R., Reinares M., Goikolea J.M., Benabarre A., Martínez-Arán A., Group psychoeducation for stabilised bipolar disorders: 5-year outcome of a randomised clinical trial, "The British Journal of Psychiatry" 2009, 194(3), pp. 260-265. 
Colom F., Vieta E., Podręcznik psychoedukacji w zaburzeniach afektywnych dwubiegunowych, MediPage, Warszawa 2009.

Colom F., Vieta E., Martinez-Aran A., Reinares M., Goikolea J.M., Benabarre A., Torrent C., Comes M., Corbella B., Parramon G., Corominas J., A randomized trial on the efficacy of group psychoeducation in the prophylaxis of recurrences in bipolar patients whose disease is in remission, "Arch Gen Psychiatry" 2003, 60(4), pp. 402-407.

Ekhtiari H., Rezapour T., Aupperle R.L., Paulus M.P., Neuroscience-informed psychoeducation for addiction medicine: A neurocognitive perspective, "Progress In Brain Research" 2017, Vol. 235, pp. 239-264.

Kordas W., Warchoł K., Kurtyka A., Walczewski K., Bogacz J., Słowik P., Psychoedukacja i psychoprofilaktyka dla rodzin osób chorujących na schizofrenię - raport z realizacji projektu, "Hygeia Public Health” 2014, 49(1), pp. 120-126.

Kowalik S., Stosowana psychologia rehabilitacji, Wydawnictwo Naukowe SCHOLAR, Warszawa 2018.

Majewicz P., Psychoedukacja jako forma stymulacji rozwoju osób z niepetnosprawnościa, [in:] Psychoedukacja w procesie wspomagania rehabilitacji osób z niepełnosprawnością, ed. P. Majewicz, M. Kościółek, E. Dyduch, Wydawnictwo Naukowe Uniwersytetu Pedagogicznego, Kraków 2017, pp. 11-24.

Majewicz P., Wolny J., Psychoedukacja jako płaszczyzna integracji działań psychologicznych, psychiatrycznych oraz pedagogicznych, "Humanum - Międzynarodowe Studia Społeczno-Humanistyczne" 2017, no. 26(3), pp. 29-48.

Majewicz P., Zawadzki A., Wspomaganie rozwoju dzieci z zaburzeniami emocjonalnymi w młodszym i średnim wieku szkolnym, [in:] W. Pilecka, Majewicz, A. Zawadzki, Jak wspomagać psychospołeczny rozwój dzieci niepełnosprawnych somatycznie. Wydawnictwo Edukacyjne, Kraków 1999, pp. 77-118.

Mączka G., Grabski B., Gierowski J.K., Dudek D., Psychoedukacja grupowa w kompleksowym leczeniu choroby afektywnej dwubiegunowej - doświadczenia krakowskie, "Psychiatria Polska" 2010, volume XLIV, no. 1, p. 89-100.

Popławska R., Czernikiewicz A., Szulc A., Galińska B., Konarzewska B., RudnikSzałaj I., Ocena efektywności psychoedukacji w grupach pacjentów psychotycznych $i$ depresyjnych - badania pilotażowe, "Psychiatria Polska" 2004, Vol. 38, no. 3, pp. 433-442.

Sawicka K., Socjoterapia, Methodological Centre of Psychological-Pedagogical Counselling Ministry of National Education, Warszawa 1998.

Wienberg G., Walther Ch., Berg M., Psychoedukacja grupowa z schizofrenii i zaburzeniach schizoafektywnych. Program PEGASUS, Wydawnictwo DK Media Poland, Warszawa 2015.

Witusik A., Leszto S., Pogdgórska-Jachnik D., Pietras T., Schizofrenia w kontekście nauk społecznych. Osoba chora na schizofrenię w obszarze zainteresowań pedagogiki specjalnej. Wydawnictwo Continuo, Wrocław 2015. 